\title{
Group Identity as a Prognostic Factor of Mental Health in Preschool Children
}

\author{
Nataliia Dysh/ova
}

Institute for Social and Political Psychology, National Academy of Educational Sciences, Kyiv, Ukraine

\begin{abstract}
Introduction. Victim stance of an individual may arise due to negative social relationships (Chojnacka, 2020) and may be associated with the experience of loneliness (Barbaro, 1999); lack of close friends and rejection by peers; lack of play partner and negative relationships in childhood (Chase, 1999). However, studies investigating the peculiarities of group identity development and the problem of loneliness in preschool children are insufficiently presented in the modern scientific literature. In this article, the phenomenon of victimhood, the experience of acceptance or rejection by a group of peers are considered in the context of preschooler's mental health genesis.
\end{abstract}

Purpose. The aim of the study is to determine the features of group identity development in preschool children in kindergartens based on the examples of children and the memories of adults.

Materials and methods: an anonymous survey with open-ended and closed-ended questions was used ( $n=247$ ). The participants of the survey were parents of preschoolers attending modern preschool educational institutions $(n=140)$ and respondents who attended kindergarten as children ( $n=107$, aged 12 to 55). They were asked to evaluate the organization of groups in kindergarten; the features of interpersonal interaction of children; meeting the needs of children in child-care facilities; the main functions of the kindergarten and their level of trust in educators.

Results: Kindergarten is a second important environment where a child continues to develop his group identity and ego-identity, and not just a place where children stay when parents are at work. Children who have difficulty interacting with their peers often face aggression from peers, experience feelings of loneliness, but not always receive help from their teachers. The majority of respondents (75.7\%) answered that the experience of communication in kindergarten influenced their emotional state, self-esteem and communicative competence at school.

Conclusions: The peculiarities of children's group identity in the preschool period are experiences of interest in interaction with a certain group of peers, the desire to be accepted and at the same time hostility towards or lack of interest in other peers. A significant percentage of experienced loneliness among modern children (35.5\%) and adults (27.1\%) who attended kindergarten more than 30 years ago indicates that this problem has existed for decades and requires more attention from scientists. Absence of play partners and frequent conflicts with peers lead to low self-esteem, fear of communication with children, other toxic experience and, as a consequence, to the risks of victimization in the future

Keywords group identity, preschoolers, loneliness, mental health, preschool institution

Address for correspondence: Nataliia V. Dyshlova. Ph.D., Institute for Social and

Political Psychology, NAES of Ukraine, Kyiv, Ukraine. natallydv@ukr.net

This work is licensed under a Creative Commons Attribution-

NonCommercial 4.0 International License (CC BY-NC 4.0).

(c) (7) (8)

Submitted for publication: 23 May 2021

Revised: 17 August 2021

(C) Copyright: Dyshlova, 2021 Accepted for publication: 18 October 2021

Licensee NDSAN (MFC- Coordinator of the NDSAN), Italy

Doi: https://doi.org/10.32437/mhgcj.v4i2.118 


\section{Introduction}

Identity means the integration of all previous identifications and self-images (Erickson, 1996).

Group identity is associated with identifying with a particular group or community and begins to form in early childhood (Erickson, 1996); and is the first form of social identity (Chorna, 2020). It is associated with identifying oneself with a particular group or community (Hornostay, 2010). At the same time, there are almost no studies dedicated to group identity development peculiarities in preschool children. In modern psychology, very few works are devoted to the problem of loneliness, especially in preschoolers. This may be due to the underestimation of the impact of loneliness in a small group on a child's mental health and personality development at an early and preschool age.

However, a developed sense of community allows children to create an adequate scheme of the world around them. The children learn to cooperate and communicate in a group, compare themselves with others, develop their self-esteem, and learn to relate their desires to the norms accepted in society. At the same time, with an underdeveloped sense of community, children begin to form neurotic complexes, inferiority complexes, which make them anxious, insecure, envious, conformist and tense. One of the main personal qualities that helps children to survive the slings and arrows of life and overcome hardships is the ability to cooperate and collaborate with others (Adler, 2016). Therefore, the harmonious development of the child's group identity is very important, because a huge number of destructive phenomena that we can observe recently cruelty, aggression, adolescent and child suicides - have their origins in early and preschool age, which can be determined by an educational strategy of a family as well as by problems in group identity development.

\section{Purpose}

The Purpose of the study is to determine the features of group identity development in preschool children on the examples of children and adults.

\section{Methodology}

An anonymous survey with open-ended and closed-ended questions was used ( $n=247$ ). The participants of the survey were parents of preschoolers aged 4-6 who attend modern preschool institutions $(n=140)$ and respondents who attended kindergarten as children $(n=107$, aged 12-55). They were asked to evaluate the organization of groups in kindergartens; features of interpersonal interaction of children; meeting the needs of children in child-care facilities; the main functions of kindergartens; their level of trust in educators.

\section{Results}

The results of the pilot study show that respondents aged 34 to 45 (50.5\%) and 26 to 35 $(33.6 \%)$ took the most active part in the survey. Such interest in the study may be associated with a general increase in parents' awareness of children's mental development and personal interest of respondents in psychologically safe social and emotional environment in preschool institutions.

Children group organization. In the majority of kindergartens $(62.9 \%)$ attended by preschoolers, the number of children in groups varies from 16 to 20 or even more; in $25.7 \%$ - from 11 to 16; in $8.6 \%$ - from 5 to 10. This is a large number of children per one or two adults, as it is almost impossible to monitor the psychological state of each child and timely address problematic situations when a conflict between children arises.

Features of interpersonal interaction of children in kindergartens. The analysis of preschoolers' parents' responses showed that children aged 46 express a strong desire to belong to a certain group: $85.6 \%$ of children prefer to communicate with a certain group of peers; $51.1 \%$ of children in the group have peers with whom they do not want to communicate. At the same time, the answers of adults show similar results: more than 30 years ago, most children in kindergartens also preferred to interact with a certain group of peers $(58.1 \%)$, and there were children with whom no one wanted to interact $(49.5 \%)$. The preservation of this trend indicates that in a small group of kindergarten, children are divided into subgroups not chaotically, but according to certain preferences. Children develop sympathy, a strong interest in certain peers, and dislike or alienation from other children. Preschoolers with whom peers refuse to interact may suffer, feel lonely, which in the future increases the risk of maladaptation in the school community. The unmet children's need to be accepted and be a part of a group increases the risks of joining online groups, which can be life-threatening.

It has been found that in a modern kindergarten, every 10th child often faces aggression from peers and complains about their loneliness. Children who feel lonely in the group say they are not accepted by their peers: "no one is friends with me" (13.3\%), "I have no friends"

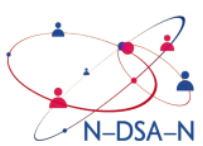


(6.7\%), "Other children play with me a little" (11.1\%), "I am insulted" (4.4\%), "usually I play alone" (20\%). An interesting fact was that $27.1 \%$ of respondents who mentioned their own experience of attending a kindergarten (most respondents attended it more than 30 years ago) also noted feelings of loneliness $15.6 \%$ of respondents always, and $21.5 \%$ - often). They noted that they felt lonely because they "had few friends in the group" (21.8\%), "were insulted by other children" (12.9\%), "were insulted by teachers" (19.8\%), "missed their parents" (67.3\%).

At the same time, the analysis of respondents' answers shows that almost half of the respondents do not know whether a teacher helps their child to overcome difficulties in communicating with peers: $45.6 \%$ of respondents cannot say whether a teacher helps their children find contact with peers, i.e. quality communication between teachers and parents is absent; $7.8 \%$ believe teachers don't help their children; $15 \%$ say their children do not need help and only 31.1\% state that teachers help the children establish contact with peers. Analyzing the experience of adult respondents, we found that most respondents also did not receive sufficient help from a teacher in building friendly relationships with peers when they needed it (29\% - never, $20.6 \%$ - sometimes received support).

This coincidence may indicate that neither thirty years ago, nor even in modern preschool institutions, due attention is not paid to the development of group identity of preschoolers. Lack of sufficient communication experience in children often leads to negative consequences in the child's personal development (Bozhovych, 1995). This means that some children feel particularly unhappy, and their self-esteem may be low, which will lead to victimization at school.

The level of trust in teachers. Most parents do not have full confidence in the staff of kindergartens attended by their children: $67.1 \%$ of parents said that the installed online surveillance would have a positive effect on their trust in the teachers, and $32.9 \%$ of respondents would no longer trust. It can be assumed that parents who do not need video surveillance have good contact with the teachers, their children like to attend kindergarten, they have a warm emotional relationship with the teachers and know how to positively resolve conflict situations or know that they can get help from an adult.

Meeting the needs of children in kindergartens. The majority of preschoolers' parents indicate that the most important need of their children is the development of communication skills for successful interpersonal interaction with peers (50.6\%). The minority of parents rated the following criteria as the most important: "develop school skills" (14.7\%), "learn self-care skills" (14.0\%). Many parents would like their child's teacher to pay more attention to the development of conflict resolution skills in children. Recalling their experience in kindergartens, the majority of respondents, in terms of significance for them from 1 to 5 points, put the attitude of teachers and friends in the first place, which confirms the importance of acceptance by peers.

\section{Discussion}

The majority of respondents (75.7\%) answered that the experience of communication in kindergarten influenced their emotional state, selfesteem and communicative competence at school. Recalling their own experience in kindergartens, the vast majority of respondents $(82.3 \%)$ said that having friends was an important criterion for their positive emotional mood. Respondents who had a positive social and emotional experience in kindergarten said that it affected their positive self-esteem (23\%), they learned to resolve conflict situations with peers (15.9\%), they easily adapted to school (43.9\%). Those who had a negative experience indicated that they had a negative self-esteem (8.4\%) and fear of communicating with peers (18.7\%). The results suggest that kindergarten is the second important environment where the child continues to develop his/her group and ego-identity, and not just a place where children stay while their parents are at work. The process of individual's awareness of belonging to a group was studied by the authors of the theory of social identity $\mathrm{H}$. Tajfel and $\mathrm{J}$. Turner. This process, which they called "group identification", is that a person, identifying her/himself with a group, seeks to evaluate it positively, thus raising the status of the group and their own self-esteem. Group identification is a dispositional formation, i.e. a setting for belonging to a certain group. It regulates person's behavior in a group and consists of three components cognitive (a person's awareness of belonging to a group and comparing his/her group with other groups), emotional (experiencing his/her belonging to a group in the form of different feelings) and behavioral (responding to others from the position of his/her group membership, not from the standpoint of an individual).

However, the studies addressing the peculiarities of group identity development and the problem of loneliness in preschool children are scantly represented in the modern scientific literature.

The limitations of our research is the use of only one research method - questionnaires, but we 
plan to continue studying the group identity of preschoolers and use a range of additional methods: observation, interviews etc. The strength of the research is the opportunity to get acquainted not only with the feedback of modern children attending kindergarten, but also with the experience of adults who attended kindergarten in their childhood. This proves the need for changes in approaches to raising children in kindergartens: paying attention to the development of group identity and helping children who have difficulty building friendships and/or feel rejected by peers.

The practical value of the study is that the results can be used in trainings for preschool teachers and for improving their professional skills on the development of group identity in preschool children. The research materials can also be used to develop policies for governmental institutions for the purpose of reorganizing preschools.

\section{Conclusions (and Future Work)}

The formation of the child's personality in preschool is characterized by active development of group identity, which is manifested in the child's experiences of interest in interacting with a certain group of peers, desire to be accepted and at the same time hostility to or lack of interest in other peers. At the same time, the approach to raising children in kindergarten is not aimed at supporting preschoolers who have difficulty interacting with peers, experience loneliness or often face aggression from peers. Helping children in problematic situations depends on the initiative and/or competence of teachers. In fact, it is more like a lottery, children who attend kindergarten have no guarantee that they will be provided with the necessary help and support in case of difficult situations with peers. Lack of play partners and negative relationships in childhood, as well as lack of friends and rejection by peers lead to painful experiences and risks of victimization in the future. The high percentage of loneliness experienced by modern children and adults who attended kindergarten more than 30 years ago indicates that this problem is not given the necessary attention. At the same time, the positive development of group identity of preschool children depends on the help of an adult in building friendly relations, development of skills of constructive conflict resolution, attention to children's emotional state and quality feedback from educator to parents.

Prospects for further research will focus on the development of group identity of preschool children in a small group of kindergarten, including finding and overcoming the causes of childhood
Ioneliness and peer rejection, as prevention of school victimization and mental health disorders in the future.

We express our sincere gratitude to the administrators of the groups on Facebook: "Mothers of Obolon" and "Mothers of Kyiv" and to the administrator of the Viber group: "Tips of a homeopath", who allowed to place questionnaires on their platforms.

\section{Conflict of interest}

The author declares that she has no conflict of interests.

\section{References}

Adler, A. (2016). Individual psychology and child development. Moscow: Institute of General Humanitarian Researches.

Barbaro de, B. (1999). Wprowadzenie do systemowego rozumienia rodziny. Kraków: Wydawnictwo (1)

Barbara, C. (2020). The Loneliness and Isolation of the Parentified Child in the Family. Paedagogia Christiana, 1/4, 83-99.

Bozhovych, L. I. (1995). Selected Works in Psychology. Personality Formation Problems (edited by D. Feldstein.) Moscow: International Pedagogical Academy.

Chase, N. D. (1999). Parentification: An Overview of Therapy, Research and Societal Issues. In N. D. Chase (ed.), Burdened Children Theory. Research and Treatment of Parentification (pp. 3-34). Thousand Oaks, London. New Delhi: Sage Publications.

Chorna, L. H. (2020). Role and group identity: definition of notions. Institute for Social and Political Psychology - National Academy of Educational Sciences of Ukraine. https://ispp.org.ua/2020/06/01/chorna-l-grolova-ta-grupova-identichnist-viznachennyaponyat/

Dubas, E. (2006). Samotność - uniwersalny „temat” życia ludzkiego i wychowania. In $\mathrm{P}$. Domeradzki, W. Tyburski (eds.), Zrozumieć samotność. Studium interdy-scyplinarne (pp. 329-349). Torun': Wydawnictwo UMK (4).

Erickson, E. (2006). Identity: youth and crisis. Moscow: Flinta; MPSU; Progress.

Hornostay, P. P. (2010). Group Identity as a Subject of Psychology of Small Groups. Scientific Studios on Social and Political Psychology, 24(27), 105-113.

Robinson, W. P. (Ed.). (1996). Social groups and identities: developing the legacy of Henri Tajfel. Oxford: Butterworth-Heinemann. 